\title{
Reflections on the past and future of urban conservation in Iran
}

\author{
Solmaz Yadollahi(D)
}

\begin{abstract}
The material authenticity of cultural heritage has been questioned by societies in which the modern paradigm of conservation has not developed from within the native culture. This paper examines the philosophical and practical traditions in Iran regarding the materiality and authenticity of past structures. By reviewing the emergence of the Western conservation paradigm in Iran, this paper highlights two key factors: the rapidness of this paradigm shift and the remarkable contradiction between the new and old paradigms. By borrowing the Deleuzo-Guattarian concept of a 'body without organs' (BwO), this paper problematises the rapidness and radicality of the paradigm shift in Iran. It suggests exploring the under-investigated possibilities between the pre-modern and modern paradigms to address the gap between native circumstances and Western standards.
\end{abstract}

Keywords: Conservation, Authenticity, Materiality, Cities, Iran, Body without organs (BwO)

\section{Introduction}

The Athenian debate over the preservation ${ }^{1}$ of the ship of Theseus is a classic example of debating notions of authenticity and preservation in Western cultures (Starn 2002). The long ideological and social background of preservation in Western cultures has been well discussed in the conservation and heritage literature. Since the age of Constantine and the Crusader States, places containing facts of and material evidence for biblical events have played an important role in preserving the Christian collective memory (Turner 2008). For centuries, archaeology and the preservation of religious relics have been supported by Christian authorities and leading institutions for spiritual and economic reasons (Wells and Stiefel 2018). Philosophically, in this approach, the matter is significant as the container of the idea or spiritual dimension of the object (Jokilehto 2006). Therefore, preserving

\footnotetext{
${ }^{1}$ In this paper, 'preservation' has a generic meaning, while 'conservation' refers to the modern institutionalised form of preservation.
}

Correspondence: solmaz.yadollahi@b-tu.de

Research fellow at Chair of Urban Management, Faculty 6, Brandenburg University of Technology Cottbus-Senftenberg, Gebäude 2A, Raum A1.01, Konrad-Wachsmann-Allee 2, 03046 Cottbus, Germany material testimonies of the past as evidence of the truthfulness of intangible values is a principle in mainstream conservation (Stovel 2007).

With this in mind, we should note that preservation has not been a widespread and routine practice for ancient and medieval masonry in Europe (Lynch 1972). Even in Western societies, the importance of relics and material authenticity was an issue for the elite, and only highly significant objects and places were preserved (ibid). Nevertheless, these traditions laid the epistemological and methodological foundations of the modern field of conservation worldwide.

In countries and cultures where the modern understanding of cultural heritage has not developed from within the native culture, heritage and conservation scholars and practitioners have questioned the principles of materiality and authenticity. Although the idea of material authenticity was expanded after the Nara Document, the conceptual limits remain challenging in urban and landscape contexts (Nishimura 2012). Today, scholars attempt to expand the epistemological boundaries of heritage and conservation by presenting alternative understandings of these concepts. In the recent heritage literature, ideas such as heritage and authenticity are considered dynamic concepts that should be understood
Springer Open
(๑) The Author(s). 2020 Open Access This article is licensed under a Creative Commons Attribution 4.0 International License, which permits use, sharing, adaptation, distribution and reproduction in any medium or format, as long as you give appropriate credit to the original author(s) and the source, provide a link to the Creative Commons licence, and indicate if changes were made. The images or other third party material in this article are included in the article's Creative Commons licence, unless indicated otherwise in a credit line to the material. If material is not included in the article's Creative Commons licence and your intended use is not permitted by statutory regulation or exceeds the permitted use, you will need to obtain permission directly from the copyright holder. To view a copy of this licence, visit http://creativecommons.org/licenses/by/4.0/. 
within diverse local and national contexts (Silverman 2015). Therefore, there is a growing interest in and need for gaining knowledge about understandings of heritagerelated concepts, particularly in countries where the modern idea of cultural heritage is not rooted in the native culture (Wu and Hou 2015). The necessity of considering the colonial and Western background of disciplines such as anthropology and archaeology, as well as institutions dealing with heritage, is also noteworthy (Macdonald 2020).

\section{Scope and approach}

The evolution of institutionalised conservation in Iran in the first half of the twentieth century was similar to that in many other Middle Eastern and even some European countries (Galdieri and Afsar 1992). Galdieri and Afsar note that the 'kind of restoration' typically practised in pre-modern and early modern Iran included major modifications or the replacement of monuments without an interest in their history. As explained in this paper, this approach was changed by the Iranian government in less than 30 years.

Investigating the manner of this change is essential due to the connections of the pre-modern restoration paradigm with the philosophical and practical traditions in Iran. The continuous line of thought connecting the ancient Zoroastrian traditions to the pre-Islamic (559 $\mathrm{BC}-651 \mathrm{AD}$ ) and Islamic periods in Iran (including the post-1979 period) makes this paradigm shift especially noteworthy. Therefore, this paper examines the literature on Iranian philosophical and practical traditions regarding the materiality and authenticity of past objects. By briefly reviewing the emergence of the Western conservation paradigm in Iran, this paper highlights two key factors: the speed of this paradigm shift and the remarkable contradiction between the new and old paradigms.

\section{A body without organs}

Political, economic, technological, and natural processes can re-order or re-territorialise cities and social organisations (DeLanda 2006; McFarlane 2011). In this DeleuzoGuattarian viewpoint, cities, organisations, and the planning paradigms that shape them are understood as dynamic social-material assemblages (Hillier 2005; McFarlane 2011).

Pointing out that Deleuze and Guattari's work is inherently about new possibilities, Purcell (2013) calls for exploring 'what planning would be like' in the future. This approach is particularly interested in the zone of virtual (not actual) possibilities before a body ${ }^{2}$ finds its organised shape. The idea of a 'body without organs' $(\mathrm{BwO})$ is one of Deleuze and Guattari's concepts referring to new possibilities of making a body (Deleuze and

\footnotetext{
${ }^{2}$ The term body here refers to social-political entities such as cities, management systems, and organisations.
}

Guattari 1987). In other words, a $\mathrm{BwO}$ is the virtual space of the potential trajectories of a body when it undergoes a transition towards becoming something new. ${ }^{3}$ This concept is interested in "what a body is capable of' becoming when it is not yet structured by a paradigm or a set of norms (Banville and Torres 2016).

$\mathrm{BwO}$ entails departing from past dogmas and being open to novel future possibilities. However, though departing from the past is essential for dynamic and creative social and organisational life, it can also be risky. Deleuze and Guattari (1987) warn that too dramatic or aggressive a break from the past or existing norms can lead to the creation of an empty body. It can provide space for a new but more rigidly dogmatic system.

I conceptualise the pre-modern and modern paradigms of dealing with past structures as becoming bodies shaped by historically embedded political-economic discourses, philosophical beliefs, and natural forces. In the political and technological climate of the late 19th and early 20th centuries, a $\mathrm{BwO}$ was formed that provided the possibility for the birth of a new paradigm for dealing with past structures in Iranian cities. I argue that the problematic transition towards establishing the modern conservation paradigm in Iran has created a new dogmatic system based on Western principles.

\section{Heritage as a social-material assemblage}

Understanding cultural heritage as a process related to 'human agency,' an 'instrument of cultural power' (Harvey 2001) or a discursive cultural process (Smith 2006) helps to explain the discursive dimensions of heritage and its uses in societies. Nevertheless, cities and the intervention paradigms that shape them are made by social discourses as well as non-discursive forces such as earthquakes, floods, and material resources (DeLanda 2006). Therefore, Harrison's (2015) assemblage-inspired approach that views heritage as a material-discursive process is compatible with the scope of this paper. By giving examples from pre-modern and early modern Iran, I suggest in this article that the function of the material and social components of built heritage as an assemblage process has changed over time.

\section{Authenticity and materiality in Iran's pre-modern philosophical positions}

Here, I consider the thoughts of some key influential thinkers in Iranian culture. These philosophical elaborations mainly have a metaphysical disposition. However, they address fundamental questions about the condition of the human being in the world, truthfulness, and

${ }^{3}$ DeLanda (2016) uses the concept of a zone of intensity or plane of consistency to refer to this transitional state. 
authenticity. Answers to such questions can potentially trigger alternative thoughts about preservation approaches.

Zoroastrian $^{4}$ thoughts have long influenced Iranian culture and post-Islamic thinkers (Ebrahimi Dinani 1987; Razi 2000). Zoroaster (Zarathustra) ${ }^{5}$ explains himself and the human being as a passenger who moves through the Giti, the material world, towards the Minoo, the land of light (Razi 2000). This transcendental journey is made possible by a sound understanding of the material world (Dhalla 1938). In other words, in Zoroastrianism, materiality is viewed as the bridge enabling one to move towards the immaterial Minoo.

In Zoroastrianism, individuals freely choose to participate in the battle between light and darkness in the world. Thus, personal conscience, enlightened by the eternal truth, is highly valued in this belief system. In fact, the truth is understood to be implicit in the cosmic order created by the source of wisdom, the Ahura Mazda (God). Zoroaster believes that the truthfulness of ideas (including old traditions) should be judged in light of the wisdom and rationality that exist in the human conscience (Mehr 1995). He also connects wisdom to the past and the idea of heritage. Viewing the light of wisdom as the primary cultural legacy of humankind, Zoroaster invites his followers to respect this legacy by reflecting on it, understanding it, and distributing it through education:

This light has been shed on us continuously from the furthest times. ... It enables us to enjoy all the wisdom of the past generations. ... It is necessary for everyone to respect the light of life that represents the entire value of the great works of past nations and tribes. (Razi 2000,37)

The 'test of fire ${ }^{6}$-practised as a judicial method in ancient Iran-is known as a symbolic form of the Zoroastrian abstract idea of judging authenticity based on wisdom (Ebrahimi Dinani 1987; Razi 2000; Zaviyeh, Dadashi and Tabar 2010). Symbolically, the fire (neutral, fearless wisdom) burns the inauthentic and untruthful and is the only proof of truthfulness because truth and fire have the same origin: God. The test of fire might not sound democratic or participatory by today's standards, but it symbolises the purity of ideas being tested by neutral judgement informed by the light of wisdom. For Zoroaster, the light of wisdom is the

\footnotetext{
${ }^{4}$ Zoroastrianism was officially practised by the Achaemenid (559-330 BC) and Sassanid (224-651 AD) empires.

${ }^{5}$ Dhalla (1938) assumes that Zoroaster, the Iranian ancient prophet, lived in approximately $1000 \mathrm{BC}$. However, there is no consensus among historians on this point.

${ }^{6}$ Individuals accused of being dishonest had to pass through fire to prove their truthfulness.
}

essential heritage of humankind and what we can learn from the past. This approach has continued in Iran's Islamic period. Islamic and Quranic teachings also emphasise the importance of spiritual values over material values (Hodjat 1995).

From the first century after the Muslim conquest of Iran, the works of Iranian philosophers, thinkers, and poets began to shape a collective, self-organised body of literary activism for preserving the Iranian pre-Islamic cultural heritage (Ashraf 2006). An important product of this movement is the epic poem (Shah-nama) written by Firdausi in the tenth century based on the history and mythology of pre-Islamic Iran (Frye 1975). Firdausi viewed wisdom as the source of all good in the world and declared the advantage and superiority of his literary work (a carrier of wisdom) over physical works:

The homes that are the dwellings of to-day Will sink 'neath shower and sunshine to decay, But storm and rain shall never mar what I Have built-the palace of my poetry.

As years pass o'er the tale that I have writ

Each man possessed of wisdom reading it. (Firdausi-e Tousi 2013, 4:42)

The Zoroastrian legacy continued to influence Iranian Islamic philosophy through the centuries (Ebrahimi Dinani 1987; Ziai 1996; Razi 2000). The Muslim Iranian philosopher Shihab al-Din Suhrawardi (1157-1191), ${ }^{7}$ founder of the Philosophy of Illumination, revitalised ancient Iranian philosophy and integrated it with the Islamic and Western schools of thought (Ziai 1996). As in Zoroastrianism, light plays a central role in his philosophy. When talking about light, Suhrawardi does not refer to natural light; light reveals itself and does not need to be revealed by something else. In this understanding, light is a metaphor for lucidity, wisdom, and knowledge (Ziai 1990). Suhrawardi argues for the authenticity and reality of light, through which the material world can be revealed and understood. $\mathrm{He}$ views materiality as a hijab (cover) that should be removed so that the light can be perceived (Ebrahimi Dinani 1987). However, like Zoroaster, he believes that to see the light, one must pass through the material.

In his essay titled 'The Sound of Gabriel's Wing,, Suhrawardi symbolically illustrates the existential relationship between divinity (light) and materiality (darkness) (Ziai 1990). Gabriel has two wings: the right is made of

\footnotetext{
${ }^{7} \mathrm{He}$ was executed in 1191 due to the incompatibility of his philosophy with the official conservative Islamic beliefs of his time (Ebrahimi Dinani 1987; Ziai 2004).

${ }^{8}$ The angel Gabriel, conventionally believed to be God's messenger in other religions, has a higher symbolic meaning in Sufism: Gabriel is metaphorically related to creation and existence.
} 
pure light, and the left has dark shadows. The wing symbolises the role of light and darkness in the human being's journey to its origin: 'We descended into the world by virtue of the very thing that will allow us to ascend' (Rustom 2020, 415). The Persian legendary bird Simorgh has a similar material-immaterial character. Simorgh can exist simultaneously in the heavens and on the earth. Suhrawardi uses these symbols to explain the condition of the human being in the world. Once 'the toil of material existence' is ended, the human can move to the upper, non-material level (Ziai 1990, 233). In Suhrawardi's works, materiality is not of central importance, but it is important enough to be the temporary bridge towards the light of wisdom.

Another figure who significantly influenced Iranian culture is Jalal ad-Din Muhammad Balkhi-Rumi (12071273). According to Ebrahimi Dinani's interpretation (2010a;2010b), in the 'Naynameh' (Song of the Reed), Rumi presents himself (and human beings in general) as a traveller (salek) on earth. A salek must be aware of the temporality of life in the material world and view it as an existential experience that helps one move towards wisdom. Rumi also views materiality as something that covers the truth. Influenced by Zoroastrianism, Islam, and Buddhism, he states that the traveller on a spiritual journey has to pass through the physical world (Ebrahimi Dinani 1987). Regarding the superiority of spiritual transcendence compared to the radical materialistic life, Rumi states in his 'Divan-e Shams':

Sufis celebrate two feasts at one moment, as spiders conserve flies. (Atashzay and Imani 2016, 131)

Here, 'spiders' refers to people who are busy with the material life, while 'flies' refers to material properties that are carefully conserved to be used later (ibid). Additionally, in the 'Masnawi', Rumi says:

Escape from here! Love of forms in this place Is not for forms themselves like a girl's face;

Why give your heart to a mere wall of clay?

Seek the light's source which shines each single day!

(Rūmì 2007, 43-44)

This approach to materiality can be traced to seventeenthcentury philosophy in Iran. Mulla Sadra (ca. 1571-1636) was the most influential philosopher during the rule of the Safavid Shah Abbas (in the late 16th and early 17th centuries). Sadra trained several significant philosophers in the Shia seminary, and his ideas have continued to

\footnotetext{
${ }^{9}$ The first 18 lines of the Mathnawi; see Balkhi-Rumi (1926).
}

influence the thoughts of contemporary Shia clergy in Iran, such as Ayatollah Khomeini, the leader of the 1979 Islamic Revolution (Rizvi 2009). As a peripatetic philosopher, Sadra's ontological and epistemological arguments differ from those of the illuminationists. However, we know that he was influenced by Suhrawardi's ideas (Ebrahimi Dinani 1987; Ziai 1996). In Sadra's philosophy, the term esalat (authenticity) refers to being real, objective, and not conceptual (Motahhari 1993). In this context, a thing or an aspect thereof is authentic if it can prove or reveal itself without dependence on something else. In Sadra's theory of Substantial Motion (haraka jawhariyya), existence is ontologically fundamental (authentic), whereas substances are abstracted from it (Eshkevari 2007).

In Sadra's ontology, past, present, and future form a continuum within which human and non-human beings are in flux. This understanding regards time as abstracted from the renewal process of the body of things (ibid). In Substantial Motion, all creatures experience several forms but ultimately depend on the authentic source (the nonmaterial source of existence). At each point in time, the human being and the world are in a stage of moving towards the non-material source of existence, or God. Here, we can trace a similar approach to materiality as a stage in the process towards the non-material truth.

Not all the reviewed thoughts agree with one another's in detail, but there is an overall consistency in their viewpoints, which form a collective body of thought related to materiality, truthfulness, and the condition of the human being in the world. If one experiments with re-thinking the concepts of heritage, authenticity, and preservation within the discussed ideological paradigm, one can suggest that in pre-modern Iran, heritage was generally understood as the knowledge of past generations to be preserved by constant reflection and transmission. Materiality was viewed as a necessary but temporary phase of human experience and a curtain that should eventually be opened to perceive the authentic meaning of heritage. This ideological position did not deny the importance of materiality as a temporal medium for practising and perceiving wisdom. However, it did not emphasise the careful keeping of material objects to preserve the wisdom or knowledge that they carry.

In this section, I provided an overview of the philosophical component of the pre-modern paradigm of dealing with past structures. The next section presents examples of planning and construction practices to show the interrelation of the discussed philosophical component and political, economic, and material factors in pre-modern cites.

\section{Pre-modern planning and construction traditions in Iran} We know that the Achaemenids (559-330 BC) were interested in learning about the history of other cultures and preserved the memory of their past through 
oral traditions, official records, and saga illustrations (Shahbazi 1990). There is no concrete evidence showing their interest in preserving the physical remains of the past, but we know that they planned their new cities according to ancient traditions and with approval from religious leaders (Habibi 1996). Ancient Iranian cities underwent major re-territorialisation processes when they were conquered by the Muslims. Examples from this period can reveal the general approach to dealing with ruins remaining from the past.

As depicted in the rudimentary plans in Figs. 1 and 2, Ardashir-Khwarrah (Firuzabad) and Darabgerd, respectively, were two significant cities of the Sassanid Empire (224-651 AD), both located in Fars Province. The fates of these cities are interestingly similar in the course of political transitions after the fall of the Sassanid Empire. Archaeological findings show that the Muslim conquerors fundamentally changed the social structure of neighbourhoods in these cities (Karimian and Seyedein 2010; Karimian and Zohuri 2014). The social changes were naturally interrelated with physical interventions. For instance, after the conquerors moved the political centre of Darabgerd outside the city walls, some old neighbourhoods were gradually abandoned, and the former royal citadel at the city centre was used for storage (Karimian and Seyedein 2010). As the cited archaeological investigations show, in the course of ideological and political changes and natural disasters, both cities experienced continuous alteration and used old material for new buildings. However, when human and economic

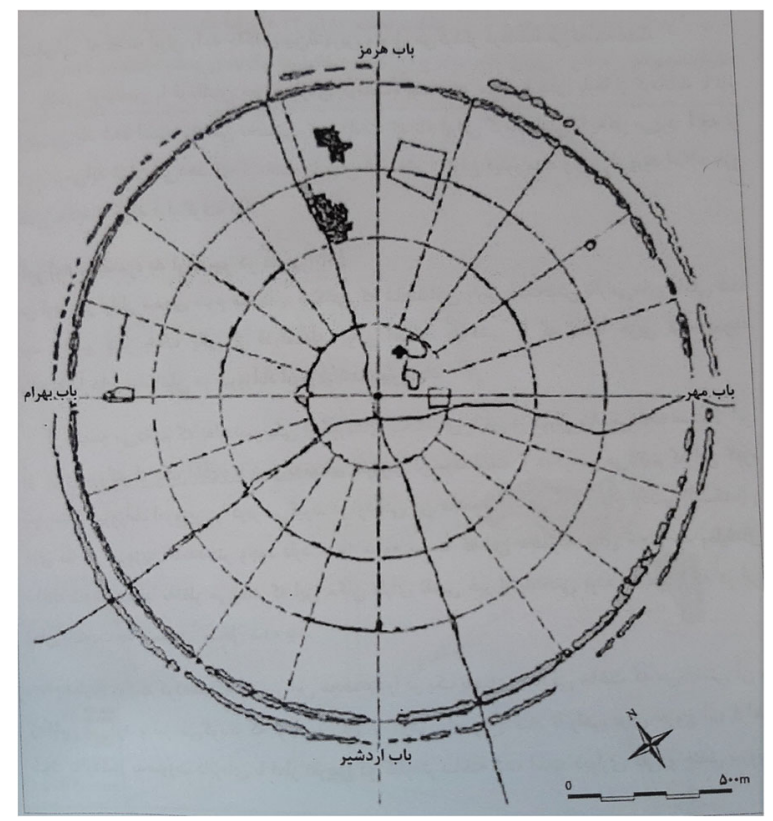

Fig. 1 Plan of Ardashir-Khwarrah (Source: Pakzad 2011, 150)

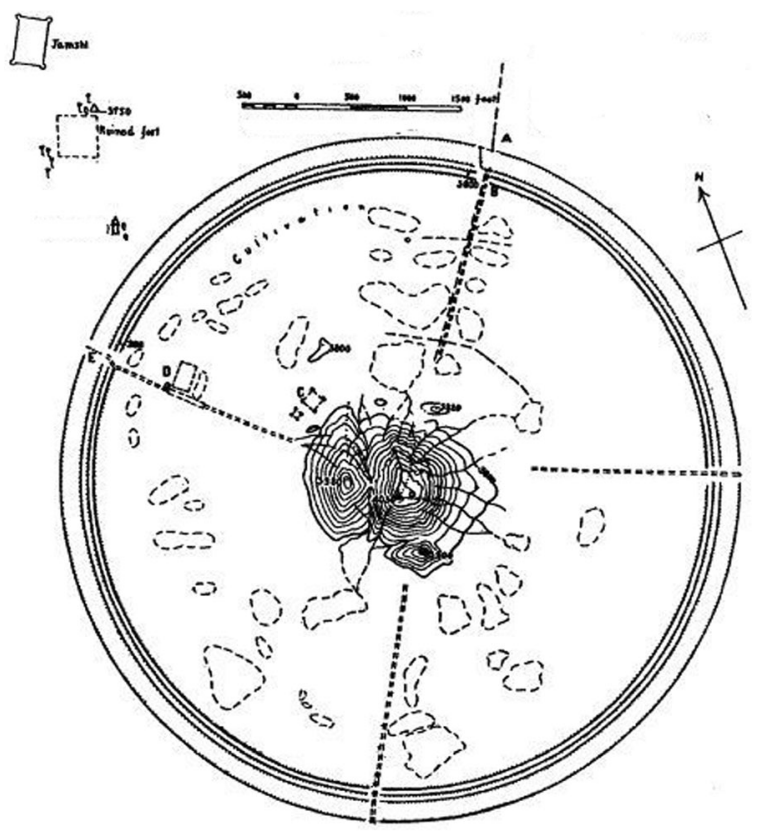

Fig. 2 Plan of Darabgerd (Source: Karimian and Seyedein 2009, 47)

resources were no longer sufficient to maintain the old neighbourhoods, they were abandoned.

Darabgerd was destroyed to punish a rebellion against the Seljuk (Turk) ruler in the eleventh century. After losing political support and consequently experiencing an economic crisis, its inhabitants abandoned the remains of the old city and migrated to a nearby village (Karimian and Seyedein 2010). Ardashir-Khwarrah's wealth declined in the tenth century when an earthquake destroyed the commercially codependent Siraf port (Karimian and Zohuri 2014). When the rest of the city's wealth was exhausted by the Mongol king's imposition of heavy taxes in the fourteenth century, the inhabitants left the old city and moved to a nearby village (ibid). In both examples, past structures were continuously re-used to the point that re-use was no longer possible or beneficial. Another important point is that the fate of the cities depended on support from the rulers.

The statements of the fourteenth-century historian Ibn-e Khaldun on the situation of many medieval Islamic capitals (including in Iran) show the same pattern of re-territorialising old cities:

... If the notables leave a city, ... this means damage to the city's structure. Then, inevitably, a new government should reconstruct the city. ... This resembles an old house with many rooms that no longer meet the owner's taste and needs. He can rebuild it [the old house] according to his desire. 
Then, he destroys the house and builds another one. (Falamaki 2005, 111)

There are several examples of historical buildings of excellent architectural and artistic quality being abandoned after losing the attention of the notables. As depicted in Figs. 3 and 4, the Blue Mosque (Masjed-e Mo affariya) and the Arg-e Alishah or Alishah Mosque in Tabriz respectively, were admired by travellers as magnificent masterpieces (Afsar 1986; Aube 2011), yet despite their beauty, both were abandoned after being destroyed by battles and earthquakes. Much of their material was later used to construct new buildings.

The ruins of the multi-functional complex that included the Blue Mosque (also known as the Sunni Mosque) were out of use by the eighteenth century under the Shia rulers (Aube 2011). Meanwhile, the Alishah Mosque, which was repaired and re-used as a mosque until the early fifteenth century, was in ruins in the late seventeenth century and was used as a citadel in 1881 (Afsar 1986). After being severely damaged in wars and earthquakes, the mosques were abandoned, and their construction material was partially re-used when their maintenance ceased to be economically or politically justifiable for local rulers. These structures were registered and restored as built heritage only in the 1970s, when the practice of modern conservation emerged in Iran.

Other old places were not abandoned following extreme political or natural shocks. Such sites were not maintained because of their historical or artistic qualities but instead were continuously repaired and reconstructed according to the construction techniques of the time and traditional craftsmanship. Pirnia (1991) explains this ongoing practice of recycling material while keeping traditional motifs and techniques by giving the

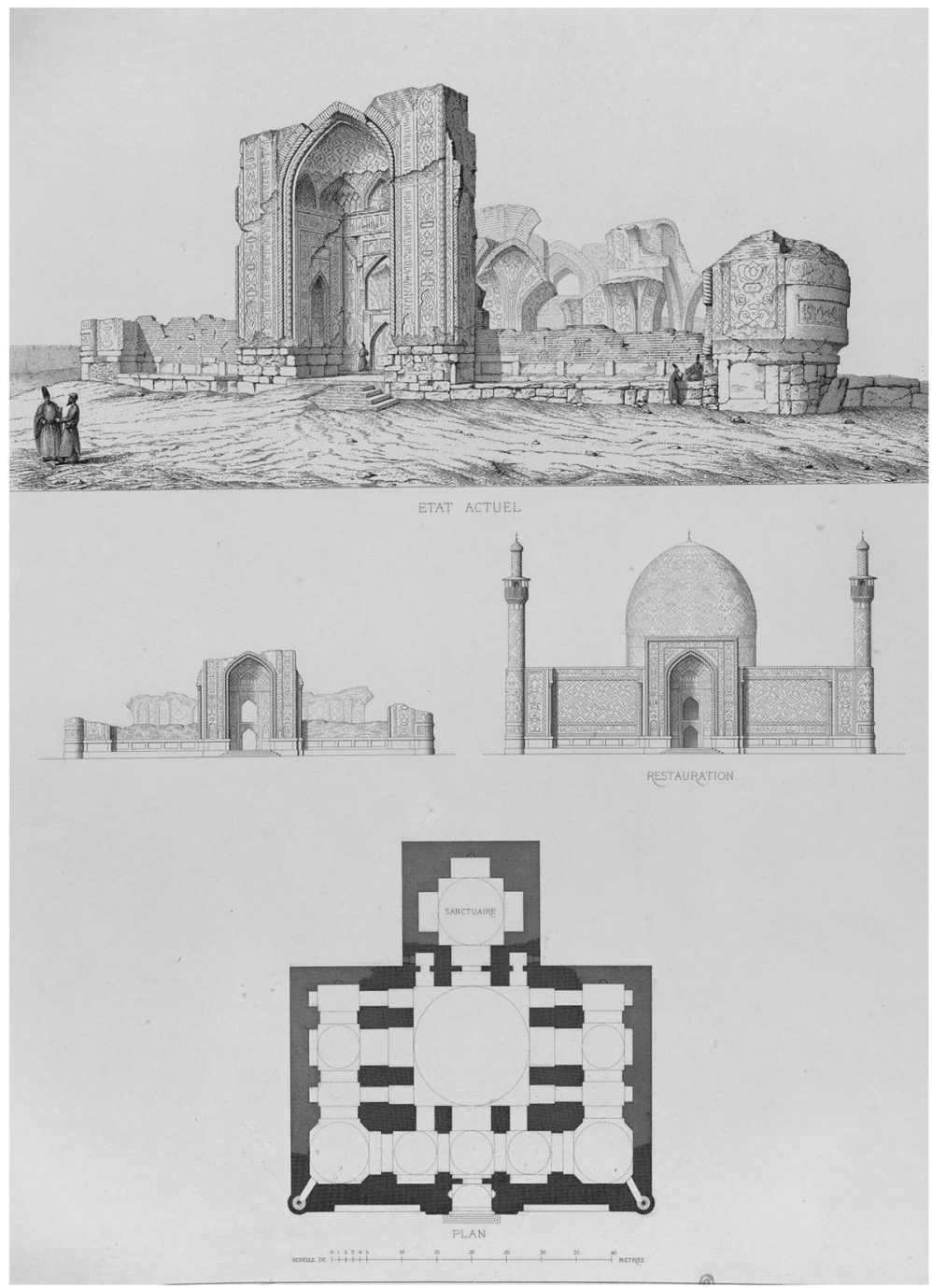

Fig. 3 Drawings of the ruined and restored states of the Blue Mosque in Tabriz (Source: Coste 1867, LXVIII) 


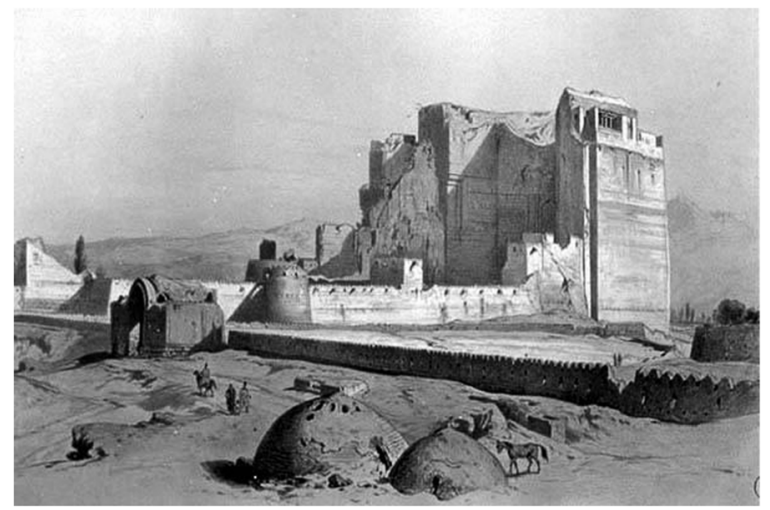

Fig. 4 The ruins of the Arg-e Alishah in Tabriz, drawn by Pascal Coste in the nineteenth century (Source: Pakzad 2011, 312)

example of Iranian tile works. The tile works followed old motifs but were designed so that single pieces could be easily replaced if damaged.

The Masjed-e Jäme of Isfahan, assumed to have been built on the site of a Zoroastrian temple in the eighth century (Babaie and Haug 2007), is a good example of an old structure undergoing constant change. Throughout centuries of use, it was altered and expanded by sponsors from different dynasties (as illustrated in Fig. 5). However, a continuous architectural tradition is observable in the course of the temple's changes. Although in its early phases, the mosque followed the simple plan of the Prophet Muhammad's mosque in Medina, the later expansions, particularly in the Seljuk period (thirteenth century), followed the typical Persian style of the FourAyvān plan with a domed chamber (ibid). This style can be traced back to pre-Islamic Sasanid buildings, for instance, in Firuzabad (Pirnia 2010). In this example, the temporality of the material and the continuity of the architectural know-how and religious beliefs that defined the form, location, and function of the building are evident.

Another excellent example is the Tabriz Bazaar in Eastern Azerbaijan Province, Iran. Tabriz experienced several earthquakes, floods, and political conflicts throughout history. After the 1780 earthquake, the bazaar was rebuilt with a similar spatial organisation, at the same location, and with similar architectural material and techniques (Yadollahi 2017). The location and spatial organisation of the 'new bazaar' followed the structure that had resulted from trade routes and private (or waqf) ownership and land-use agreements. The bazaar was rebuilt several times and developed after each reconstruction because the commercial city of Tabriz depended on its existence. Thus, rebuilding the bazaar was a priority for the notables and merchants.

The records of town renewal in Tabriz after the 1870 flood show the same approach to repairing and renewing

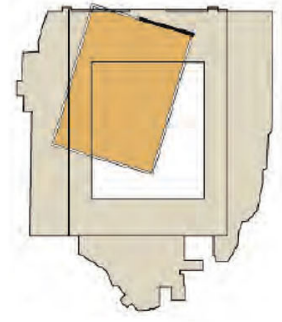

OMAYED PERIOD (8 \& 9th AD)

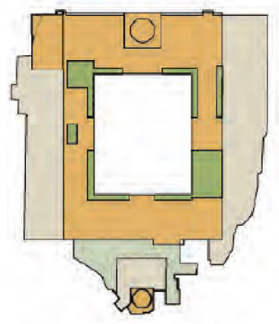

ILKHANID PERIOD (OL JAITO) (14th AD)

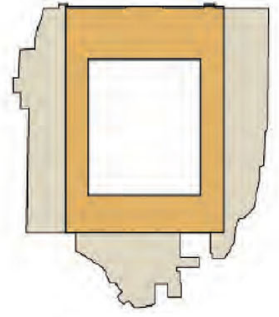

ABHASID PERIOD (10th AD)

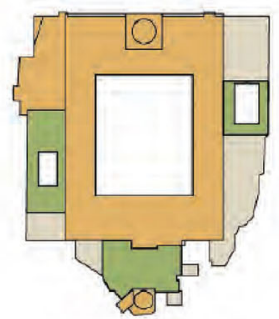

ILKHANID PERIOD 2 (MOZAFARID) (15th AD)

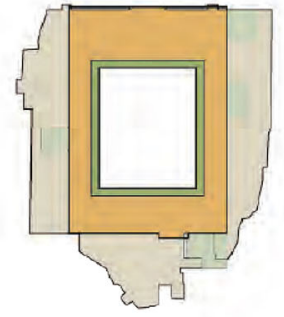

BUYID PERIOD

(11th AD)

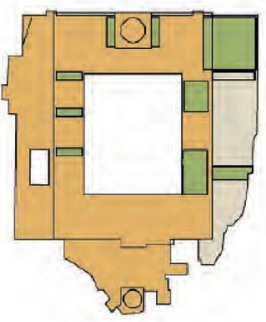

TIMURID PERIOD (16th AD)

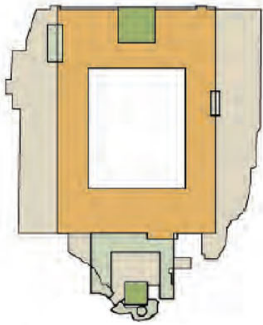

SELIUD PERIOD 1

(12th AD)

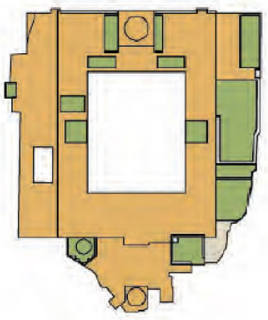

SAFAVID PERIOD (17th AD)

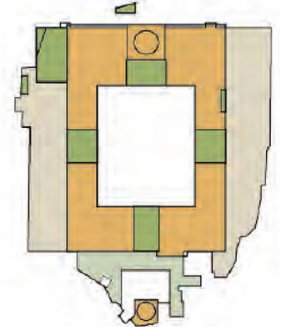

SELIUQ PERIOD 2 SOLTAN SANJAR (13th AD)

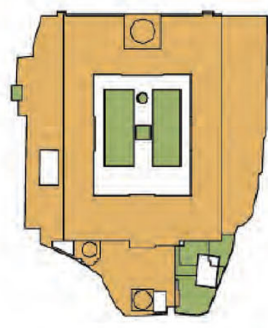

QAIAR PERIOD (18-19th AD)

Fig. 5 Historical changes in the Masjed-e Jäme' of Isfahan between the 8th and 19th centuries (Source: ICHHTO 2011, 186) 
the old structures. The 1870 flood map (Fig. 6) and accompanying sketches depict the destruction of houses and public buildings, such as a mosque, bath-houses, the ice reservoir, the bazaar, and some caravanserais. The map was prepared for a report to the ruler on the state of destruction after the flood and the planned renewal activities.

After each de-territorialisation triggered by an earthquake, war or flood, the bazaar as a social-material entity knew (did not imitate or hastily fake) how to build and update a massive brick structure, how to adapt to the local topography and changing social agreements, and how to plug itself into the changing flow of regional and continental trade. The traditional paradigm of becoming a bazaar organised the bazaar's $\mathrm{BwO}$ during each transition. This paradigm was responsive until the unprecedented technological and political changes of the early twentieth century.

The Tabriz Bazaar, the Alishah Mosque, and the Blue Mosque all experienced the same natural and political shocks in Tabriz. The stories of these places demonstrate that the abandonment or use of a city's past structures was a matter of pragmatic justification. Nostalgic, technical, or aesthetic values embodied in places played no role in the fate of their material components. They were re-shaped by a similar traditional paradigm, as Tavassoli's (2016) investigation of the post-Islamic development of cities such as Yazd, Shiraz, and Kashan confirms.

In the Iranian pre-modern paradigm, the material component of human beings and objects was viewed as a necessary but temporary part of their life process. In this paradigm, metaphysical, intellectual and practical knowledge was the essential and lasting part of heritage. Here, knowledge refers to 'knowing that,' transmitted by language, and 'knowing how', or embodied knowledge, which depends on the material medium and learning through practice (DeLanda 2016). Acknowledging the necessity and temporality of the role of the material component is key to understanding the Iranian premodern approach to authenticity.

DeLanda (2006) views traditions as repertories of rules and rituals with an ordering or coding function, particularly in small organisations. He notes that in modern bureaucratic organisations, rational-legal rules play this coding role. In the reviewed examples, the traditional

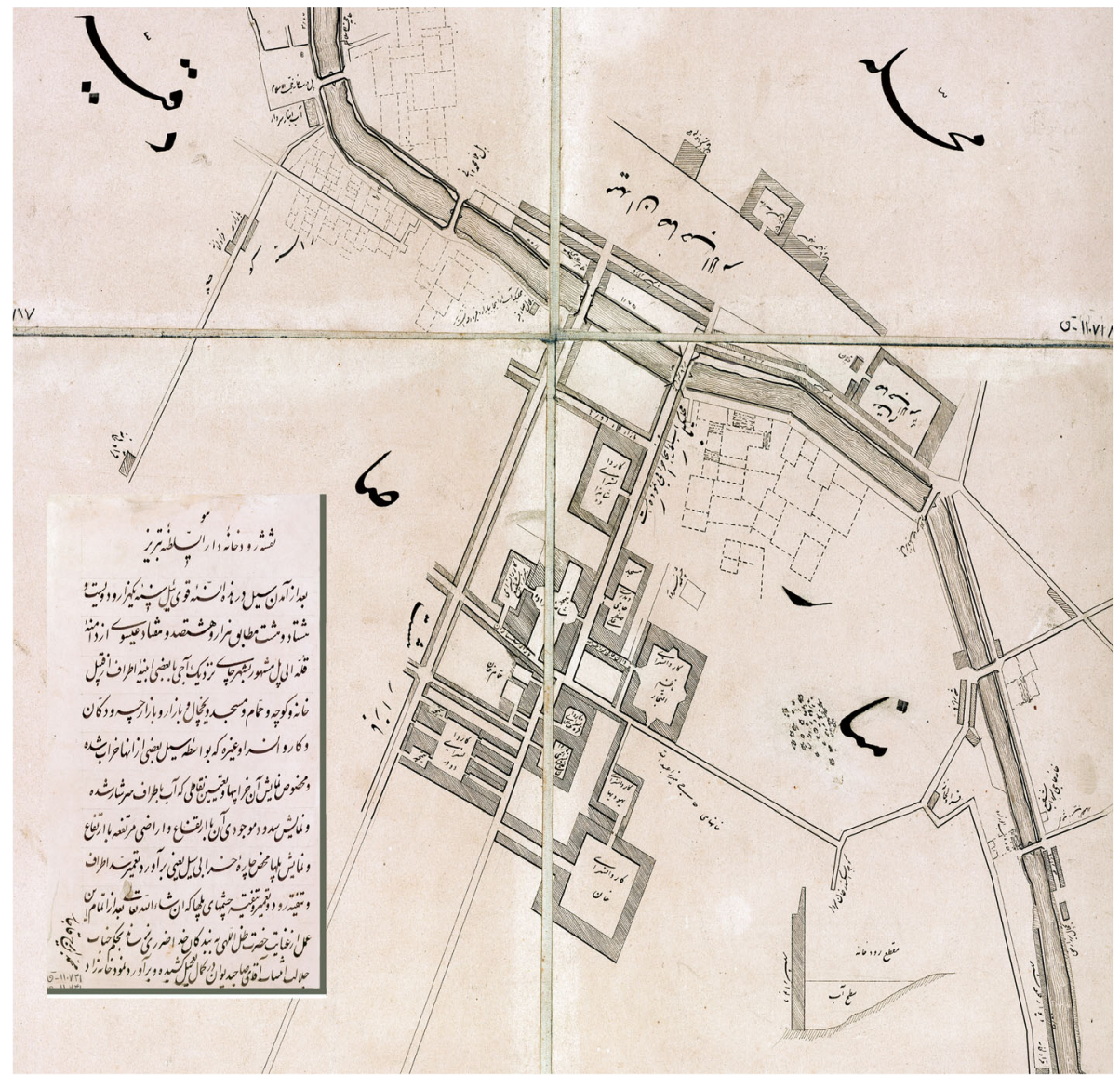

Fig. 6 The map prepared for town renewal in Tabriz after the 1870 flood (Source: ICHHTO 2009, 274) 


\section{The modern philosophical approach to the materiality of heritage:}

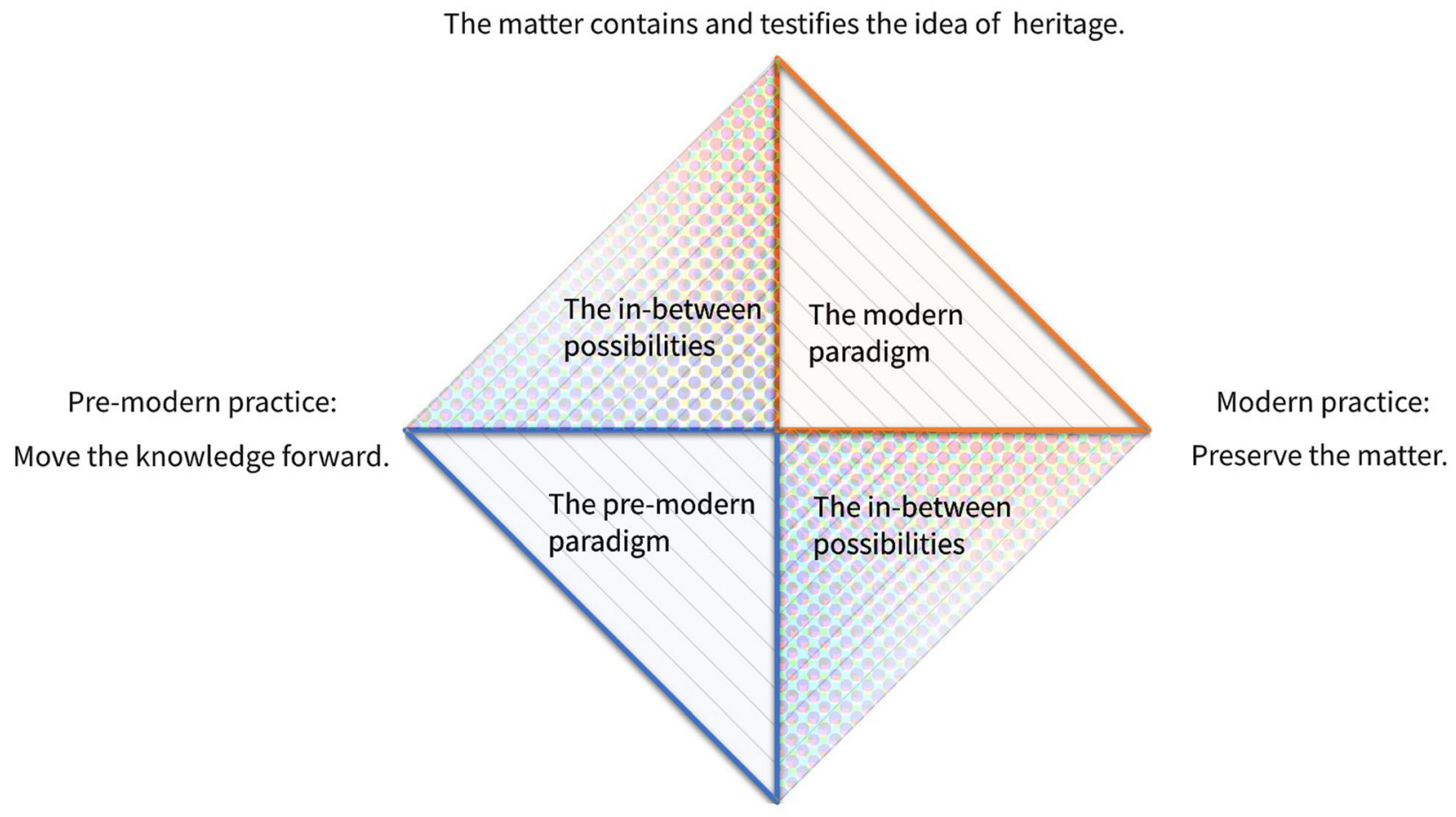

The pre-modern philosophical approach to the materiality of heritage:

The matter temporarily leads you to the idea of heritage, but if you hold to it, it conceals the key idea.

Fig. 7 A proposal for investigating possible ways of thinking about the materiality and authenticity of the Iranian urban heritage (Source: the author)

paradigm defined what should be kept and what should be left to go to ruin in pre-modern cities. In the modern conservation paradigm, a legal-bureaucratic system replaced the old tradition.

In the early twentieth century, when the transition of traditional Iranian cities to bureaucratic organisations became inevitable, a $\mathrm{BwO}$ or a plane of possibility for creating a new paradigm for dealing with past structures emerged. However, the rapid and careless departure from the outmoded but complex and profoundly rooted native paradigm emptied this $\mathrm{BwO}$.

\section{The emergence of centralised heritage conservation}

An early example of using historic sites to promote a city's political image is the measures introduced by Hajji Muhammad Hussain Khan Sadr, the governor of Isfahan in 1795, the Qajar prime minister in 1806, and ambassador to England. Sadr attempted to revive the glory of Isfahan by restoring the Safavid seventeenth-century buildings and building new Safavid-style buildings and gardens (Walcher 2000). Although Sadr's interventions are close to the modern understanding of conservation, these activities depended on him as an individual, not an established system that promoted conservation. After Sadr, when the Qajar prince Mass'oud Mirza Zell-e Soltan became governor of Isfahan in 1872, the recycling of the material of old structures began again, directed by Zell-e Soltan himself and other Qajar notables (Adili 2017). ${ }^{10}$ In general, the nineteenth century was characterised by the appearance of some scattered desires for preservation as a result of political and economic relationships with Europe.

The early drivers of systematic preservation in Iran appeared during the late nineteenth century, when Western archaeology entered the country. The political philosopher Tabatabai (2006) contends that this period was characterised by a strong desire for modernity, as the Iranian elite reacted to the long-term decline in the production of progressive political thought.

Modern archaeological excavations began in Iran during the rule of Naser al-Din Shah (1831-1896), who is well known for his passion for art, photography, and travelling to Europe. The shah sponsored some archaeological excavations and assembled a personal collection

\footnotetext{
${ }^{10}$ In his documentary film, Adili interviewed prominent historians and scholars.
} 
of antiquities (Abdi 2001). He also ordered the preservation of historic buildings such as the fourteenth-century mausoleum of Oljaytu. ${ }^{11}$ However, according to the private diaries of E'temad-al-saltana, his chief ferash (servant), his interest was rather superficial and a personal hobby (Nikzad and Nazari 2007). Therefore, his approach was criticised by some of the notable elite. Such notables paved the way for the idea of state-led archaeology and heritage conservation in Iran. One of these figures was Hajj Sayyah (1836-1925), who complained about the lack of awareness in Iran of the importance of preserving relics:

I have not seen a country as miserable as Iran or a nation as unfortunate as Iranians. Other countries not only preserve every menial remain left behind by ancient commoners of their own country with much effort, but spend a great deal to take antiquities of other lands to their country, investigate its date and its makers with painstaking accuracy and, indeed, are proud of this. (Abdi 2001, 53)

These bitter words may explain the strong desire of the Iranian elite for rapid change in how society dealt with past structures. This desire was a part of the political environment that led to modern nation-state relationships through the 1906 Iranian Constitution. This marked the beginning of the formation of a centralised legal-administrative apparatus for urban planning and heritage conservation. It was in this period that the elite started to criticise the behaviour of local governors towards historic sites. Faraj-e Bad Az Shedat, ${ }^{12}$ one of Isfahan's constitutional newspapers, published an article about the brutal destruction and abuse of historical buildings of Isfahan by Zell-e Soltan (Adili 2017).

The concurrence of the growing interest in archaeology, nationalist movements ${ }^{13}$ and the demand for rapid modernisation had a significant influence on how the conservation paradigm unfolded in early-twentiethcentury Iran.

The first written law on the state-led conservation of cultural heritage was enacted in 1910, establishing the Ministry of Knowledge, Awqaf, and Handicrafts (Vezarate Maaref, Awqaf, va Sanaye' e Mostazrefeh). This law refers to historic and cultural properties as 'vadaye' $e$ melli', or 'national trust'-one of the first Persian terms with a meaning and function similar to those of the

\footnotetext{
${ }^{11}$ Soltaniyeh is now a World Heritage site.

${ }^{12}$ It was founded in 1907.

${ }^{13}$ An example is the writings of Mirzā Āqā Khan Kermānī from the early generation of Iranian nationalists (Bayat 2015). Kermānī was executed in 1896, but as Grigor (2004) observes, nationalism appeared later in the cultural policy discourse of post-Constitution Iran.
}

modern term 'national heritage'(Nasirzadeh, Abdollahi and Sayebani 2009).

In 1922, the Anjoman-e Athar-e Melli (AAM; National Monuments Council of Iran) was established by modernist notables with the cooperation of foreign advisors such as Ernst Herzfeld, head of the German Institute of Oriental Archaeology. Reza Khan Sardar-e Sepah (later Reza Shah) was the honorary president of the AAM in 1925 (Sadiq 1985). As declared in its mandate, the council's aims were to build museums and libraries, list and document historical monuments, and make them available to the regular public. In the mid-1920s, Reza Shah and his allies at the AAM were eager to use modern architecture and historic monuments to define the future of Iran based on the heritage of the pre-Qajar and particularly the pre-Islamic past (Grigor 2004).

Herzfeld, Godard, ${ }^{14}$ and Foroughi ${ }^{15}$ played leading roles in writing the 1930 Law for Protection of National Works and Monuments, or the Antiquities Law (Nasirzadeh et al. 2009). This law has been fundamental to the establishment of Iran's current legal-administrative apparatus for heritage conservation. The establishment of this centralised apparatus can be seen as a mid-term project. It was ordered by the state, coordinated by the elite, and executed in consultation with Western orientalists over a period of approximately 25 years. Subsequently, Western orientalists remained directly involved in conservation activities in Iran until the 1979 Islamic Revolution (Mahdizadeh and Shojaei 2018).

In the 1930s, the national urban modernisation project altered the traditional social and spatial structure of many Iranian cities based on Haussmann's nineteenthcentury renovation model for Paris (Habibi 1996). The concurrent beginning of urban master plans and modern conservation created a contradictory process in urban planning policy and practice. While modern planners instigated the rapid replacement of the old city fabrics by perpendicular networks of streets, conservation authorities simultaneously selected particular monuments for listing and preservation.

In less than 30 years, the approach to regular built structures of the past changed from gradually recycling their material to rapid replacement. Regarding politically or aesthetically significant monuments, the paradigm shifted from renewal to conservation. In the new system, monuments and the (often) nationalist political message they carried became heritage. They were listed, conserved, politically interpreted, and promoted by the state. The European notion of material authenticity became essential

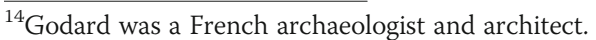

${ }^{15}$ Foroughi was an Iranian writer and politician.

${ }^{16}$ The Centre for Iranian Anthropology, founded in 1938, was appointed to document Iranian culture and folklore (Fazeli 2006).
} 
for the credibility of the message these monuments were supposed to display. At the same time, metaphysical, intellectual and practical knowledge was documented in academic texts and state archives ${ }^{16}$ but ignored in planning practice. The modernisation of Tehran, based on Western scientific planning while neglecting its urban culture, historic city centre, and bazaar, is an example of this planning approach (Madanipour 2010; Mashayekhi 2019).

\section{Discussion and conclusion}

As in Western countries, modern conservation in Iran started as an interest of the elite and was then centralised by the state. However, two significant factors distinguished the beginning of modern conservation in Iran from its emergence in most Western countries. First, the pre-modern and modern paradigms of dealing with heritage and materiality in Iran were contradictory. Second, Iranians' shift from the pre-modern paradigm to the modern approach was especially rapid. These two factors make Iran a comparable case, particularly to countries with a similar cultural and philosophical background.

Tabatabai (2004) asserts that conservative insistence on dysfunctional traditions and the superficial imitation of Western ideas have both caused deviations in cultural and political transformation in Iran. In shaping the new preservation paradigm, the Iranian government chose the path of hasty imitation rather than a cumulative process of internalising and adapting the imported Western paradigm. This led to the assembly of the current centralised and dogmatic conservation system based on Western norms. In other words, the modern conservation system grew into an empty body that lacked enough connections with the past and could not respond to domestic geographical and cultural complexities. Although the current Iranian conservation system struggles with non-native standards, it avoids selfreflection for economic and political reasons. Rather than self-reflection, the current system tends to continue to imitate because imitation is economically safe and fast and can project superficial harmony with the mainstream paradigm.

If we accept that the assembly of the modern apparatus of heritage conservation in Iran was problematic, we can approach the present struggles from a different perspective. Suppose those involved in urban conservation view the current conservation paradigm as a becoming body ${ }^{17}$ rather than a fixed dogma. In that case, we have not only the option but also the responsibility to doubt what we have imitated since the early twentieth century. We can collectively consider looking back and investigating the virtual plane of possibilities, the $\mathrm{BwO}$ of contemporary Iranian conservation. In asking what

\footnotetext{
${ }^{17}$ As Hillier (2005) views planning as 'becoming planning'.
}

alternative paths we could have pursued back then, we could find possible movements or lines of flight that we can initiate in the future. If we become lost in this investigative experiment, we can return to the mainstream paradigm and test other un-actualised possibilities between the native and modern paradigms (Fig. 7):

This is how it should be done: lodge yourself on a stratum, experiment with the opportunities it offers, find an advantageous place on it, find potential movements of de-territorialisation, possible lines of flight, experience them, produce flow conjunctions here and there, try out continuums of intensities segment by segment, have a small plot of new land at all times. (Deleuze and Guattari 1987, 178)

\section{Abbreviations \\ AAM: Anjoman-e Athar-e Melli (The National Monuments Council of Iran); BwO: Body without Organs; ICHHTO: Iranian Cultural Heritage Handicrafts and Tourism Organisation}

\section{Acknowledgements}

The author wishes to thank the anonymous reviewers at Built Heritage for their constructive critique.

\section{Author's contributions}

All tasks of the literature review, writing, and editing are done by Solmaz Yadollahi. The author(s) read and approved the final manuscript.

\section{Funding}

Thanks to the German Research Foundation (DFG) for supporting this research. The section of this paper on Iran's pre-modern philosophical positions is part of the preliminary work for the funded research.

Availability of data and materials

This paper is mainly based on the cited literature and documents.

Ethics approval and consent to participate

Not applicable.

\section{Competing interests}

Not applicable.

Received: 9 September 2020 Accepted: 8 December 2020

Published online: 29 December 2020

\section{References}

Abdi, Kamyar. 2001. "Nationalism, Politics, and the Development of Archaeology in Iran." American Journal of Archaeology, no. 105:51-76. https://doi.org/10. 2307/507326

Adili, Amir A'la. 2017. Sense of Spring (Booy-e Farvardin). Documentary film. Studio Kanoon-e Agahi-e Honar.

Afsar, Keramatollah. 1986. Arg-e 'Ališăh. London: Encyclopedia Iranica, I(4): 396397.

Ashraf, Ahmad. 2006. Iranian identity III. Medieval Islamic Period. New York: Encyclopedia Iranica, XIII (5):507-522.

Atashzay, Yahya, and Behrooz Imani. 2016. "Some Statements about 'Do Eyd-e Sanaei'". Hadighe al-Haghighe, no.10:129-144.

Aube, Sandra. 2011. Tabriz X. Monuments X(1). The Blue Mosque. New York: Encyclopedia Iranica.

Babaie, Sasan, and Robert Haug. 2007. Isfahan x. Monuments (3) Mosques. New York: Encyclopedia Iranica.

Balkhi-Rumi, Jalalad-Din Muhammad. 1926. The Mathnawi of Jalaluddin Rumi. Edited by Reynold Alleyne Nicholson. London: The Cambridge University Press. 
Banville, Marie-Sophie, and Juan Torres. 2016. "On Embracing an Immanent Ethics in Urban Planning: Pursuing Our Body-Without-Organs." Planning Theory, no. 16:255-274. https://doi.org/10.1177/1473095215625707 SAGE Publications. Bayat, Mangol. 2015. Āqā khan Kermānī. New York: Encyclopedia Iranica.

DeLanda, Manuel. 2006. A New Philosophy of Society: Assemblage Theory and Social Complexity. London \& New York: Bloomsbury Publishing.

DeLanda, Manuel. 2016. Assemblage Theory. Edinbugh: Edinburgh University Press.

Deleuze, Gilles, and Felix Guattari. 1987. A Thousand Plateaus. Translated by Brian Massumi. Minneapolis: University of Minnesota Press.

Dhalla, Maneckji Nusservanji. 1938. History of Zoroastrianism. New York: Oxford University Press.

Ebrahimi Dinani, Gholamhossein. 1987. Shoa'e Andishe dar Falsafe-ye Suhrawardi [The Circles of Thought and Intuition in Suhrawardi's Philosophy]. Tehran: Hekmat.

Ebrahimi Dinani, Gholamhossein. 2010a. Sharh-e Msnawi [Interpretation of the Masnawi], IVideo. Tehran: IRIB TV4, Marefat TV Program.

Ebrahimi Dinani, Gholamhossein. 2010b. Sharh-e Msnawi [Interpretation of the Masnawi], IIVideo. Tehran. Tehran: IRIB TV4, Marefat TV Program.

Eshkevari, Mohammed Fanaei. 2007. "Mulla Sadra's Theory of Substantial Motion." In Substance and Attribute, edited by Christian Kanzian and Muhammad Legenhausen: 25-44. Berlin, Boston: De Gruyter. https://doi.org/10.1515/ 9783110328974.25

Falamaki, M. Mansour. 2005. Seiri dar Tajarob-e Marammat-e Shari, as Veniz ta Shiraz [An Essay on Urban Conservation, from Venice to Shiraz]. Tehran: Faza scientific and cultural institute.

Fazeli, Nematollah. 2006. Politics of Culture in Iran. Persian Studies. Oxon: Routledge.

Firdausi-e Tousi, Abu I-Qasim. 2013. The Shahnama of Firdausi. Vol. 4. Translated by Arthur George Warner and Edmond Warner. Oxon: Routledge.

Frye, Richard Nelson. 1975. The Cambridge History of Iran. Vol. 5. Cambridge History Ebook Collection. Cambridge: Cambridge University Press.

Galdieri, Eugenio, and Kerāmat-Allāh Afsar. 1992. Conservation and Restoration of Persian Monuments. New York: Encyclopedia Iranica.

Grigor, Talinn. 2004. "Recultivating 'Good Taste': The Early Pahlavi Modernists and Their Society for National Heritage." Iranian Studies, no. 37:17-45. https://doi. org/10.1080/0021086042000232929.

Habibi, Mohsen. 1996. Az Shar ta Shahr [De la Cite a la Ville]. Tehran: University of Tehran.

Harrison, Rodney. 2015. "Beyond 'Natural' and 'Cultural' Heritage: Toward an Ontological Politics of Heritage in the Age of Anthropocene." Heritage \& Society, no. 8: 24-42.

Harvey, David C. 2001. "Heritage Pasts and Heritage Presents: Temporality, Meaning and the Scope of Heritage Studies." International Journal of Heritage Studies, no. 7: 319-338. https://doi.org/10.1080/13581650120105534 Routledge.

Hillier, Jean. 2005. "Straddling the Post-Structuralist Abyss: Between Transcendence and Immanence?" Planning Theory, no. 4: 271-299. https:// doi.org/10.1177/1473095205058497 Sage Publications London, Thousand Oaks, CA and New Delhi.

Hodjat, Mehdi. 1995. "Cultural Heritage in Iran: Policies for an Islamic Country." PhD diss., University of York.

ICHHTO. 2009. World Heritage Nomination Dossier of Tabriz Historical Bazaar Complex. Tehran: Iranian Cultural Heritage, Handicrafts, and Tourism Organization, Deputy of Cultural heritage.

ICHHTO. 2011. World Heritage Nomination Dossier of Masjed-e Jāme of Isfahan

Jokilehto, Jukka. 2006. "Considerations on Authenticity and Integrity in World Heritage Context." City \& time, no. 2: 1.

Karimian, Hassan, and Sasan Seyedein. 2009. "Recovery of Ancient Cities by Referring to the Historical Texts, Case Study: Darabgerd." BAGH-E NAZAR, no. 6:69-82 SID.

Karimian, Hassan, and Sasan Seyedein. 2010. "A Preliminary Survey at the Circular City of Darabgird, Iran." Antiquity Project Gallery, no. 84:42.

Karimian, Hassan, and Majid Montazer Zohuri. 2014. "Ardeshir Koreh az Sheklyabi ta Zaval ba Estenad be Motun-e Tarikhi." [Ardashir Khwarah, from Establishment to Fall on the Basis of Historical Texts.] Iranian Studies, no. 4(2): 65/83. https://doi.org/10.22059/JIS.2015.56678.

Lynch, Kevin. 1972. What Time Is This Place? Cambridge: MIT Press.

Macdonald, Sharon. 2020. "Transforming the Ethnographic." In Across Anthropology: Troubling Colonial Legacies, Museums, and the Curatorial, edited by Margareta von Oswald and Jonas Tinius, 49-64. Leuven: Leuven University press. https://doi.org/10.2307/j.ctv125jqxp.7.

Madanipour, Ali. 2010. "The Limits of Scientific Planning: Doxiadis and the Tehran Action Plan." Planning Perspectives, no. 25: 485-504. https://doi.org/10.1080/ 02665433.2010.505066 Routledge.

Mahdizadeh, Sara, and Reyhaneh Sadat Shojaei. 2018. "The Involvement of Western Orientalists in Cultural Heritage Affairs During the Pahlavi Era, Iran (1925-1979)." Journal of Architectural Conservation, no. 24: 169-184. https://doi.org/10.1080/13556207.2018.1537028 Routledge.

Mashayekhi, Azadeh. 2019. "The 1968 Tehran Master Plan and the Politics of Planning Development in Iran (1945-1979)." Planning Perspectives, no. 34 849-876. https://doi.org/10.1080/02665433.2018.1468805 Routledge.

McFarlane, Colin. 2011. "The City as Assemblage: Dwelling and Urban Space. " Environment and Planning: Society and Space, no. 29: 649-671.

Mehr, Farhang. 1995. "Social Justice in Ancient Iran." In Social Justice in the Ancient World, edited by Kaikhosrov D. Irani and Morris Silver, 75-90. London: Greenwood Publishing Group.

Motahhari, Morteza. 1993. Osool -e Falsafa va Ravesh -e- Realism [The Principles of Philosophy and the Method of Realism]. Vol. 3. 3rd ed. Tehran: Sadra.

Nasirzadeh, Behnaz, Mohsen Abdollahi, and Alireza Sayebani. 2009. "Barresi-e Hemayet-e Keyfari as Amval-e Farhangi da Hoghugh-e Iran." [Assessing the Penal Protection of Cultural Properties in the Iranian Law.] Do-fasInameye Takhasosi-e Danesh-e Maremat va Miras-e Farhangi, no. 3 (3): 45-63.

Nikzad, Zatollah, and Farhad Nazari. 2007. "Memari dar Darbar-e Soltan-e Sahebgharan" [Architecture in the Court of Naser Al-din Shah.] Golestan-e Honar, no. 9: 26-51.

Nishimura, Yukio. 2012. "Path Between Authenticity and Integrity." In Conservation Turn - Return to conservation: Tolerance for Change, Limits of Change: Proceedings of the International Conferences of the ICOMOS, International Scientific Committee for the Theory and the Philosophy of Conservation and Restoration, 5-9 May 2010, Prague Český Krumlov, Czech Republic, 3-6 march 2011, Florence, Italy. Firenze: Polistampa. https://doi.org/10.1400/191288.

Pakzad, Jahanbakhsh. 2011. History of Iranian City, from Begin to Qajar Dynasty. Tehran: Armanshahr.

Pirnia, Mohammad Karim. 1991. "On Traditional Architecture and Urban Construction in Iran." Abadi, no. 1: 4-15.

Pirnia, Mohammad Karim. 2010. In Sabk Shenasi-e Memari-e Iran [Stylistics of the Iranian Architecture]. Edited by Ali Mohammad Rnjbar Kermani. Tehran: Soroush-e Danesh.

Purcell, Mark. 2013. "A New Land: Deleuze and Guattari and Planning." Planning Theory \& Practice 14 (1): 20-38. https://doi.org/10.1080/14649357.2012. 761279.

Razi, Hāshem. 2000. Hekmat-e Khosrovāni. Tehran: Behjat.

Rizvi, Sajjad. 2009. "Mulla Sadra." In The Stanford Encyclopedia of Philosophy (Summer 2009 Edition), edited by Edward N. Zalta.

Rūmī, Jalāl al-Dīn. 2007. The Masnavi, book two. Translated by Jawid Ahmad Mojaddedi. Oxford: Oxford University Press.

Rustom, Mohammed. 2020. "Storytelling as Philosophical Pedagogy: The Case of Suhrawardī." In Knowledge and Education in Classical Islam: Religious Learning Between Continuity and Change, vol. 2, 404-416. Leiden: Brill.

Sadiq, I. 1985. Anjoman-e Athar-e Melli. London: Encyclopedia Iranica.

Shahbazi, A. Shapur. 1990. "Early Persians' Interest in History." Bulletin of the Asia Institute, no. 4: 257-265.

Silverman, Helaine. 2015. "Heritage and Authenticity." In The Palgrave Handbook of Contemporary Heritage Research, 69-88. London: Springer.

Smith, Laurajane. 2006. Uses of Heritage. London: Routledge.

Starn, Randolph. 2002. "Authenticity and Historic Preservation: Towards an Authentic History." History of the Human Sciences, no. 15: 1-16. https://doi. org/10.1177/0952695102015001070.

Stovel, Herb. 2007. "Effective Use of Authenticity and Integrity as World Heritage Qualifying Conditions." City \& Time, no. 2: 21-36.

Tabatabai, Javad. 2004. Ta'amoli Darbareh-ye Iran [On Iran]. Naghed.

Tabatabai, Javad. 2006. Maktab-i Tabriz va Mabani-i Tajaddud Khahi [The School of Tabriz and the Foundations of the Quest for Modernity]. Tehran: Sutudih.

Tavassoli, Mahmoud. 2016. Urban Structure in Hot Arid Environments, Strategies for Sustainable Development. The Urban Book Series. Cham: Springer.

Turner, Michael. 2008. "Values of Heritage in Great Religious and Cultural Areas: From Existentialism to Historicism-a View of the Holy Land and the Sites of Jesus and the Apostles." InValues and Criteria in Heritage Conservation: Proceedings of the International Conference of ICOMOS, ICCROM, Fondazione 
Romulado Del Bianco : Florence, March 2nd-4th 2007, edited by Andrzej Tomaszewski,1000-1007. Firenze : Polistampa. https://doi.org/10.1400/104699. Walcher, Heidi. 2000. "Face of the Seven Spheres: The Urban Morphology and Architecture of Nineteenth-Century Isfahan (part two)." Iranian Studies, no. 33: 327-347. https://doi.org/10.1080/00210860008701985.

Wells, Jeremy C., and Barry L. Stiefel. 2018. "Introduction: Moving Past Conflicts to Foster an Evidence-Based, Human-Centric Built Heritage Conservation Practice." In Human-Centered Built Environment Heritage Preservation, 1-30. New York: Routledge.

Wu, Zongjie, and Song Hou. 2015. "Heritage and Discourse." In The Palgrave Handbook of Contemporary Heritage Research, 37-51. London: Palgrave.

Yadollahi, Solmaz. 2017. "The Iranian Bazaar as a Public Place: A Reintegrative Approach and a Method Applied Towards the Case Study of the Tabriz Bazaar." PhD diss, Brandenburg University of Technology.

Zaviyeh, Said, Iraj Dadashi, and Ameneh Mafi Tabar. 2010. "Tahlil-e Mazmooni-e Chnad Nemuneh az Negareh-hay-e gozar-e Siyavash bar Atash dar Shahname-ye Ferdowsi." [Paintings of "Passing of Siyavash Through the Fire": An Analysis.] Adabiyat-e erfani va ostureh-shenkhti, no. 6: 56-78.

Ziai, Hossein. 1990. "Beyond Philosophy: Suhrawardı's Illuminationist Path to Wisdom." In Myth and Philosophy: Toward a Comparative Philosophy of Religions, edited by Frank E. Reynolds and David Tracy, 215-243. New York: SUNY Press.

Ziai, Hossein. 1996. "The Illuminationist Tradition." In History of Islamic Philosophy, edited by Seyyed Hossein Nasr and Oliver Leaman, 465-496. London \& New York: Routledge.

Ziai, Hossein. 2004. "Suhrawardi on Knowledge and the Experience of Light." In The Presence of Light: Divine Radiance and Religious Experience, edited by Matthew T. Kapstein, 26-27. Chicago: University of Chicago Press.

\section{Publisher's Note}

Springer Nature remains neutral with regard to jurisdictional claims in published maps and institutional affiliations.

\section{Submit your manuscript to a SpringerOpen ${ }^{\circ}$ journal and benefit from:}

- Convenient online submission

- Rigorous peer review

- Open access: articles freely available online

- High visibility within the field

- Retaining the copyright to your article

Submit your next manuscript at $\boldsymbol{\nabla}$ springeropen.com 